\title{
EFEKTIFITAS PEMBELAJARAN HADITS TEMATIK DENGAN SOFTWARE DAN APLIKASI SHAMELA LIBRARY DI MADRASAH ALIYAH AN-NUR AL-HUDA NGAWONGGO TAJINAN MALANG
}

\author{
Abdul Wahid ${ }^{1}$, Febriana Santi Wahyuni ${ }^{2}$ \\ ${ }^{1,2)}$ Teknik Informatika, Institut Teknologi Nasional Malang \\ wahidfilosof@gmail.com
}

\begin{abstract}
ABSTRAK
Artikel ini membahas hasil penelitihan tentang pemanfaatan media teknologi informasi yang berupa software dan aplikasi shamela library (Al-Maktabah As-Syamilah) untuk efektifitas pembelajaran hadits tematik di Madrasah Aliyah An-Nur Al-Huda Ngawonggo Tajinan Malang. Untuk membuka kitab-kitab hadits, bila dilakukan secara manual, maka akan membutuhkan waktu lama, dan harus membuka rak lemari yang berisi puluhan jilid kitab hadits. Dengan lahirnya software dan aplikasi ini para pelajar dan para peneliti studi Islam sangat cepat, mudah, dan efektif dalam mengakses ratusan lieteratur Islam, khususnya kitab-kitab hadits. Dengan demikian, pengetahuan, pengembangan, dan pemanfaatan media teknologi informasi untuk pendidikan Islam dan aspek kehidupan yang lain menjadi sangat urgen dan sangat penting.
\end{abstract}

Keyword : Efektifitas, Pembelajaran, Hadits, Tematik, Aplikasi, Shamela

\section{PENDAHULUAN}

Pesatnya kemajuan teknologi-khususnya teknologi informasi di bidang software dan aplikasi, mempunyai implikasi positif pada seluruh aspek kehidupan, tidak terkecuali di bidang pengajaran materi agama. Memberi dampak kemudahan untuk studi Islam, khususnya untuk pembelajaran hadits dan pengembangannya sebagai sumber kedua dalam hukum Islam setelah Al-Quran.

Di antara sisi positif perkembangan teknologi informasi ini adalah lahirnya beberapa software dan aplikasi studi Islam seperti Al-Maktabah AsSyamilah (shamela library). Software dan aplikasi ini merupakan terobosan yang sangat fenomenal dalam peradaban Islam modern. Aplikasi yang dishare secara gratis ini memuat puluhan ribu judul kitab-kitab referensi studi Islam, mulai disiplin ilmu Al-Quran, tafsir, hadits, akidah, sejarah, bahasa, akhlak, dan lain sebagainya.

Al-Maktabah As-Syamilah (المكتبة الثاملة) ini sangat membantu dan memudahkan para pemula, pebelajar tingkat lanjutan, dan lebih-lebih para peneliti dan pemerhati materi-materi keislaman. Karena dengan aplikasi ini para pembaca/user dalam waktu hitungan detik sudah bisa memperoleh data tentang tema-tema tertentu dalam satu bidang kajian. Misalnya, user ingin mendapatkan tema "berbuat baik dan berbakti kepada kedua orangtua/ "بِرٌ الوَالِآَيْنِ "yang terdapat seluruh kitab-kitab hadits,

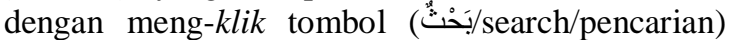

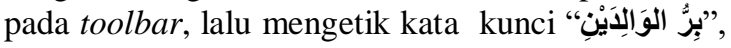
maka akan muncul lebih dari 200 lokasi buku di dalam seluruh kitab hadits yang ada di dalam aplikasi tersebut.

Nilai efektifitas yang paling istimewa pada aplikasi ini sebagai media pembelajaran adalah cakupannya yang sangat komprehensif dalam menampilkan informasi buku. Misalnya, jika bila meng-klik tema di atas pada menu (بَـَ/search/pencarian), maka mesin pencarian ini akan menunjukkan halaman, volume (jika lebih dari satu volume), penulis, penerbit, kota terbit, dan cetakan, tahun terbitan, bahkan jika ada juga dituliskan nama penyunting (muhaqqiq). Jika salah ketik atau tema yang dicari tidak termuat dalam aplikasi ini akan memberi informasi sebagaimana umumnya $e$-book atau $e$-library.

Dari sekian ratus kitab hadits, $80 \%$ sudah beharakat. Sehingga para user pemula dan masyarakat umum bisa memahami cara baca dengan baik. Sedangkan untuk penerjemahannya bisa mengunakan kamus yang tersedia pada aplikasi ini. Menurut kronolgi waktu launcingnya aplikasi ini, seharusnya aplikasi Al-Maktabah As-Syamilah ini sangat membantu para pemula, atau pelajar tingkat lanjutan di seluruh bidang keislaman, termasuk di bidang hadits, setidaknya mengenal dengan baik manfaat dan kegunaan software dan aplikasi.

Ironinya, sunguhpun aplikasi ini sudah beredar sejak awal tahun 2000-an, sampai saat ini para pebelajar ilmu keislaman, tidak banyak yang bisa mengunakannya. Banyak pelajar di sekolah-sekolah Islam atau pondok pesantren tidak bisa memanfaatkannya, atau kurang bisa memanfaatkannya dengan baik lantaran terbatasnya informasi atau kurangnya sosialisasi dari para user yang sudah lebih awal menggunakannnya.

Ironisnya lagi, banyak sekolah-sekolah yang berlabel Islam sekalipun, masih belum bisa memanfaatkannya, dan balum mengenalnya. Padahal dari masa lahirnya software dan aplikasi ini sampai saat ini (2017) sudah berusia lebih 10 tahun. Ini menunjukkan kurangnya sosialisasi dan pengenalan software dan aplikasi ini kepada 
khalayak masyarakat Islam secara umum, khususnya sekolah-sekolah atau pondok pesantren.

Kelangkaan diadakanya pelatihan aplikasi $\mathrm{Al}$ Maktabah As-Syamilah (المكتبة الشاملة) adalah penyebab utama rendahnya jumlah pengguna. Di kalangan pesantren yang menjadi user hanya para ustadz-ustadz yang belajar otodidak dan para pecinta ilmu agama. Sedangkan di kalangan masyarakat umum aplikasi ini terkesan sangat asing walaupun sudah berusia puluhan tahun. Padahal, pengunaannya sangat mudah, software-nya pun gratis, dan segala yang terkait penggunaannya relatif tidak sulit.

Sekolah-sekolah Islam seperti Madrasah Aliyah An-Nur Al-Huda Ngawonggo Tajinan Malang, adalah salah satu sekolah Islam yang belum begitu familiar dengan software ini. Pembelajaran hadits masih murni menggunakan text book seperti kitab riyadhusshalihin, mukhtarul ahadits, dan lainlain. Pemanfaatan teknologi masih sangat rendah. Padahal dengan memanfaatkan teknologi, kehidupan ini akan lebih mudah dan lebih murah, termasuk dalam proses pengajaran dan pembelajaran.

Seperti mempelajari tema "berbuat baik dan berbakti kepada kedua orangtua/بِرُ الَوَالَدَيْنِ “, bila menggunakan buku manual, dalam hitungan 30 menit, mungkin masih baru dapat 1 buku hadits. Tetapi dengan menggunakan teknologi, dalam hitungan detik akan mampu membuka 50 kitab hadits. Dengan menggunakan aplikasi ini, dalam hitungan 5 detik, user/pelajar studi Islam sudah bisa mengakses dan membaca 40 buku hadits terkait tema tersebut.

\section{TINJAUAN PUSTAKA}

Softaware shamela library ini merupakan perangkat lunak komputer gratis berbasis Microsoft Windows yang berbentuk Pembaca (reader) buku elektronik dan perpustakaan digital. Mesin ini mempunyai fleksibilitas untuk ditambahkan berkas (file) buku elektronik hingga puluhan ribu kitab atau buku. Aplikasi ini memiliki berbagai macam fitur seperti pencarian cepat (بحث), pencatatan, referensi silang, portabelitas dan berbagai kemudahan lainnya seperti copy data buku, baik berbentuk word atau pdf sesuai kebutuhan user (http://maktabahsyamilah.com/).

Software ini sangat dikenal kalangan pesantren, akademisi, dan cendekiawan muslim di seluruh belahan dunia. Karena software mampu menjawab tuntutan kebutuhan para pelajar atau pembaca kitab-kitab bahasa arab-moderen. Karena software dan aplikasi ini memuat beragam kitabkitab ulama Islam klasik dan kontemporer yang menjadi rujukan umat Islam dunia internasional, seperti:

1. Kitab Tafsir (seluruh jenis)

2. Kitab Hadits (seluruh kitab)

3. Kitab Aqidah (seluruh aliran)

4. Kitab Fiqh (seluruh aliran)

5. Kitab Adab

6. Kitab Umum

7. Kamus

8. Kitab Fahros/Indeks dll.

Software Al-Maktabah As-Syamilah Versi 2 mempunyai kemampuan menampilkan menu bahasa Arab dari kanan ke kiri dan juga teks naskah kitab dengan baik namun terbatas pada versi Windows ME hingga XP dan dipastikan mengalami masalah tampilan di Windows Vista dan 7. Adapun versi 3 tidak ada masalah dalam menampilkan teks naskah bahasa Arab baik pada versi Windows Vista maupun 7. Kemudian pada versi 2 tidak memiliki fasilitas untuk menambahkan berkas buku elektronik berkekstensi PDF.

(https://id.wikipedia.org/wiki/Maktabah_Syamilah)

\subsection{Pengenalan Ketik Huruf Arab}

Semua menu yang terdapat di dalam software dan aplikasi المكتبة الثاملة/shamela library menggunakan bahasa Arab. Oleh karena itu, sebelum menggunakan software dan aplikasi المكتبة الثاملة/shamela library ini, user harus mengetahui dan mampu mengetik dengan huruf Arab pada keyboard laptop. Untuk itulah, sebelum aplikasi dibuka, pengguna/user harus melalui langkahlangkah sebagaimana pada gambar-gambar berikut:

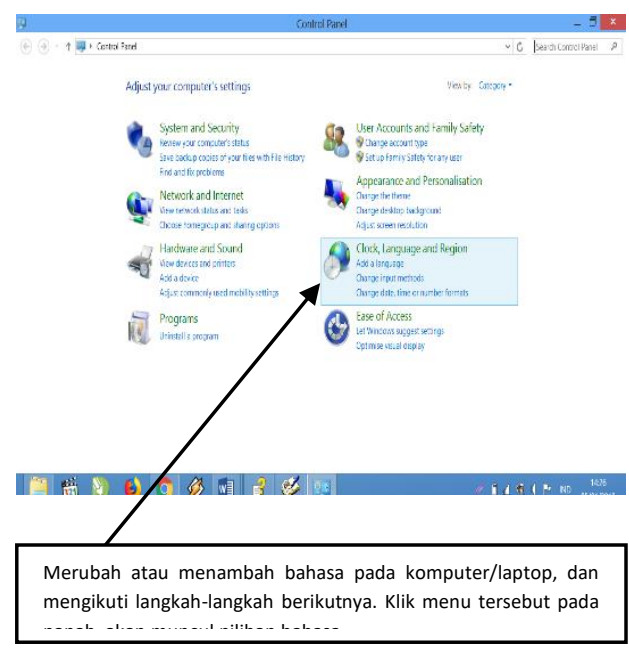

Gambar 1. Langkah 1.

Mengubah Ketik Huruf Arab Pada Komputer 


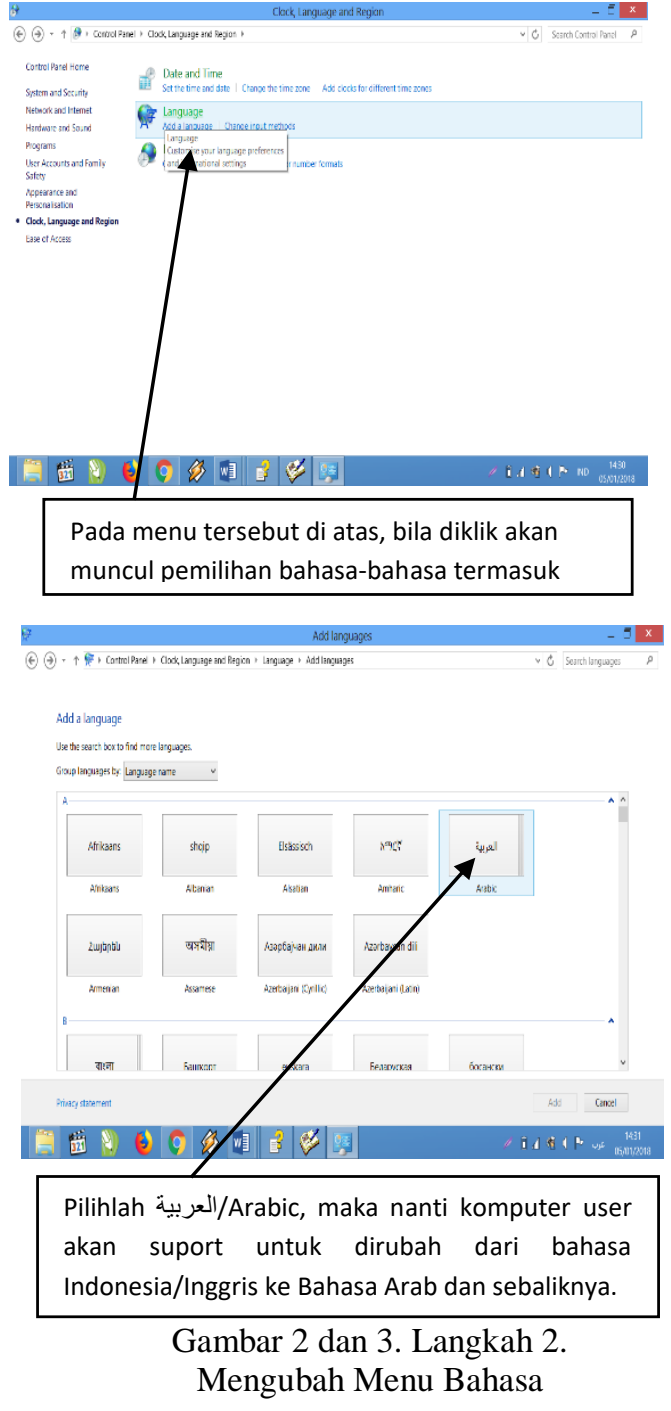

2.1.2. Mengubah Huruf Arab Pada Keyboard

Untuk mengubah hasil ketik pada keyboard dari latin/indonesia/inggris ke bahasa Arab sangatlah mudah, cukup tekan Alt.+Sift sisi kanan, maka akan berubah ketik arah kanan ke kiri/bahasa Arab. Untuk mdengembalikan dari Arab ke latin/indonesia/inggris, cukup tekan Alt.+ Sift sisi kiri, maka ketik huruf akan berubah dari kiri ke kanan.

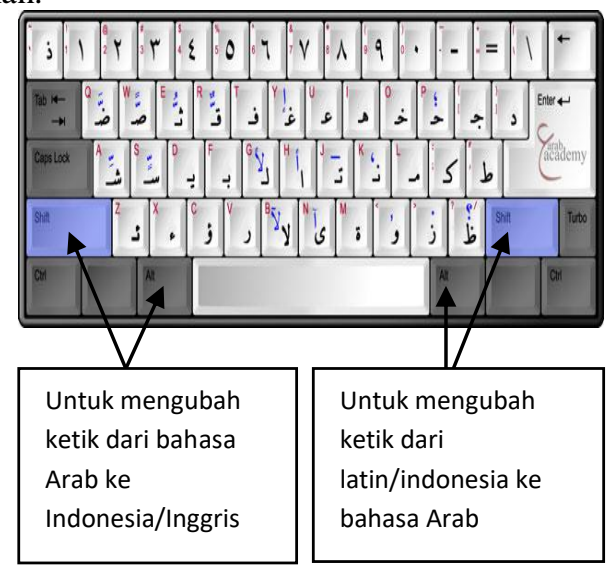

Gambar. 4. Keyboard

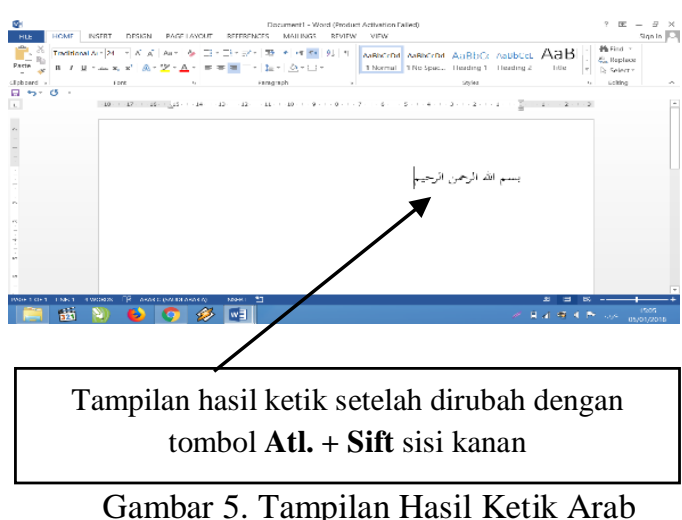

Bila laptop atau $P C$ sudah bisa dipastikan ketik huruf arab, maka langkah berikutnya adalah menginstal software shamela liberary. Penggunaan bahasa pada software dan aplikasi ini semuanya berbahasa Arab. Sehingga bisa diasumsikan bahwa yang bisa memanfaatkannya adalah user/pengguna yang mempunyai kemampuan bahasa Arab yang cukup baik. Selain praktik, keberadaan modul pengantar dan panduan penggunaan software dan aplikasi ini menjadi sangat penting bagi user untuk penguasaan yang lebih komprehensif.

\subsubsection{Petunjuk Instal Aplikasi}

Secara umum instal aplikasi shamela library atau Al-Maktabah As-Syamilah yang disebut juga perpustakaan Islam digital, sama dengan aplikasi lain. Bahkan saat ini (2017) aplikasi ini sudah release versi baru yang memuat 6111 kitab. Semua gratis, dan jika buku-buku yang berupa e-book ini dibeli bentuk hardcopy, maka 1 judul buku bisa berharga Rp. 3.000.000 sampai Rp. 4.000.000. Yang sangat luarbiasa, buku-bukunya di dalam digital library ini bisa ditampilkan dalam bentuk word dan pdf sekaligus bisa dicopy-paste untuk kepentingan studi Islam dalam seluruh disiplin ilmu keislaman. Bahkan kitab yang terbaru sekalipun, seperti الفقه التفسير المنير yang terdiri 11 voleme, dan الإسلامي و أدلته terdiri dari 30 volume diimport ke dalam aplikasi ini, yang jika user membeli hardcopy-nya seharga +_ Rp. 4.500.000.

Sebelum instal, user bisa mengakses beberapa situs resmi di internet, atau langsung meng-copy dari komputer user lain, tanpa harus izin kepada pemilik hak ciptanya, dalam hal ini Saudi Arabia. Karena software ini walaupun kontennya berisi ribuan judul kitab atau buku, oleh pemerintah Saudi Arab diwakafkan kepada seluruh umat Islam, atau para pembaca yang ingin belajar Islam. 


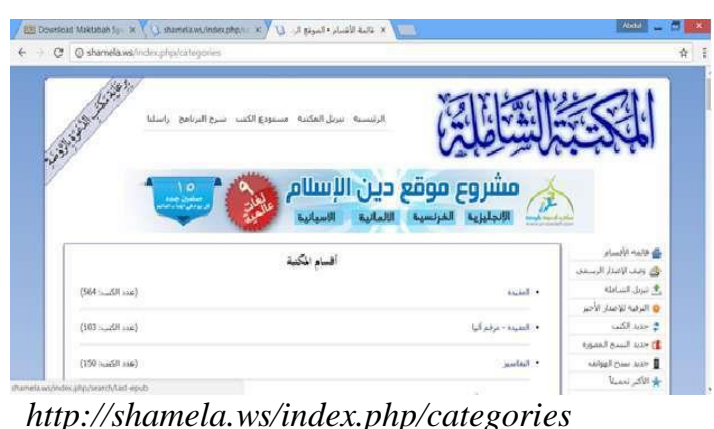

http://shamela.ws/index.php/categories

Gambar 6. Situs Resmi Download Software

Situs ini adalah situs resmi yang membagikan kitab-kitab studi Islam secara gratis, dan bukubukunya sekaligus di-upgrade setiap hari, dan seluruh disiplik keilmuan Islam dan atau yang dihasilkan oleh umat Islam.

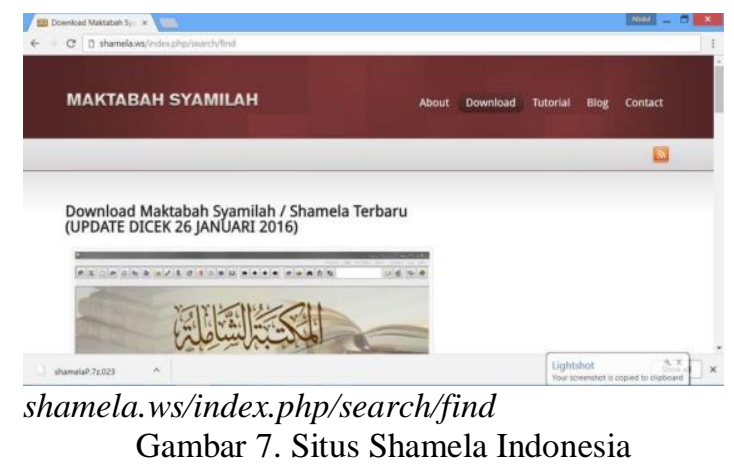

Untuk gambar 7. adalah yang dikelola oleh user Indonesia, yang kitab-kitabnya tidak sebanyak yang ada pada gambar 6. Apabila user sering membuka situs gambar 6., maka akan selalu mendapat informasi buku terbaru.

\section{METODE PENELITIAN}

Metode penelitian dimulai dengan persiapan penelitian, pengamatan, survei pustaka, survei kurikulum Madrasah Aliyah An-Nur Al-Huda Ngawonggo Tajinan Malang, survei materi, dan informasi tentang pemanfaatan teknologi informasi untuk pembelajaran hadits serta efektifitasnya, khususnya software dan aplikasi shamela library.

Pada tahap ini persiapan, segala kebutuhan penulis data dalam bentuk pengelompokan antara kebutuhan primer dan sekunder. Kemudian masuk tahapan pembuatan soal-soal untuk menguji efektifitas aplikasi untuk pembelajaran hadits tematik. Selanjutnya ada pengujian pakar untuk efektifitas aplikasi ini. peneliti melibatkan beberapa ustadz untuk mengamati dan mengevaluasi, sekaligus melakukan komparasi antara belajar hadits secara manual memakai buku, dengan menggunakan aplikasi ini. Berikut skemanya:

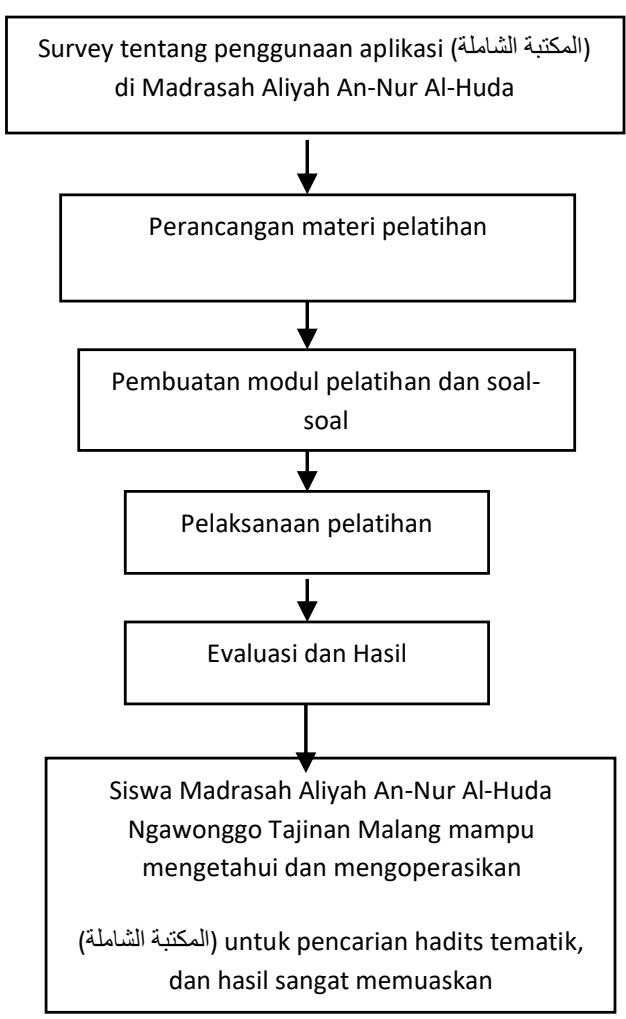

Gambar 8. Persiapan Penelitian

Dari pemaparan singkat di atas metode yang peneliti gunakan adalah metode analisis konten dan komparasi. Analisis isi adalah penelitian yang bersifat pembahasan mendalam terhadap isi suatu informasi tertulis atau tercetak dalam bentuk karya tulis yang diterbitkan atau berupa manuskrip. Analisis ini biasanya digunakan pada penelitian kualitatif. Dalam hal ini membanding antara belajar hadits tematika yang menggunakan buku manual, dengan buku digital. Perbandingan ini bertujuan untuk mengetahui sejauh mana efektifitasnya pembelajaran dengan memanfaatkan teknologi dan manual. Adapun media-media yang peneliti gunakan adalah:

Adapun alat-alat penelitian yang digunakan dalam adalah:

1. Modul pelatihan

2. Software Shamela Library

3. Lab komputer MA. An-Nur Al-Huda

4. Mouse masing-masing siswa

5. Keyboard

6. Printer tuk cetak hasil belajar

7. Buku-buku hadits manual

\section{HASIL DAN PEMBAHASAN}

Rancangan media dalam penelitian ini meliputi pengenalan ketik huruf Arab, pengadaan software, instal software, dan modul pelatihan untuk seluruh peserta, diakhiri praktek dan evaluasi. Adapun rinciannya adalah sebagai berikut: 


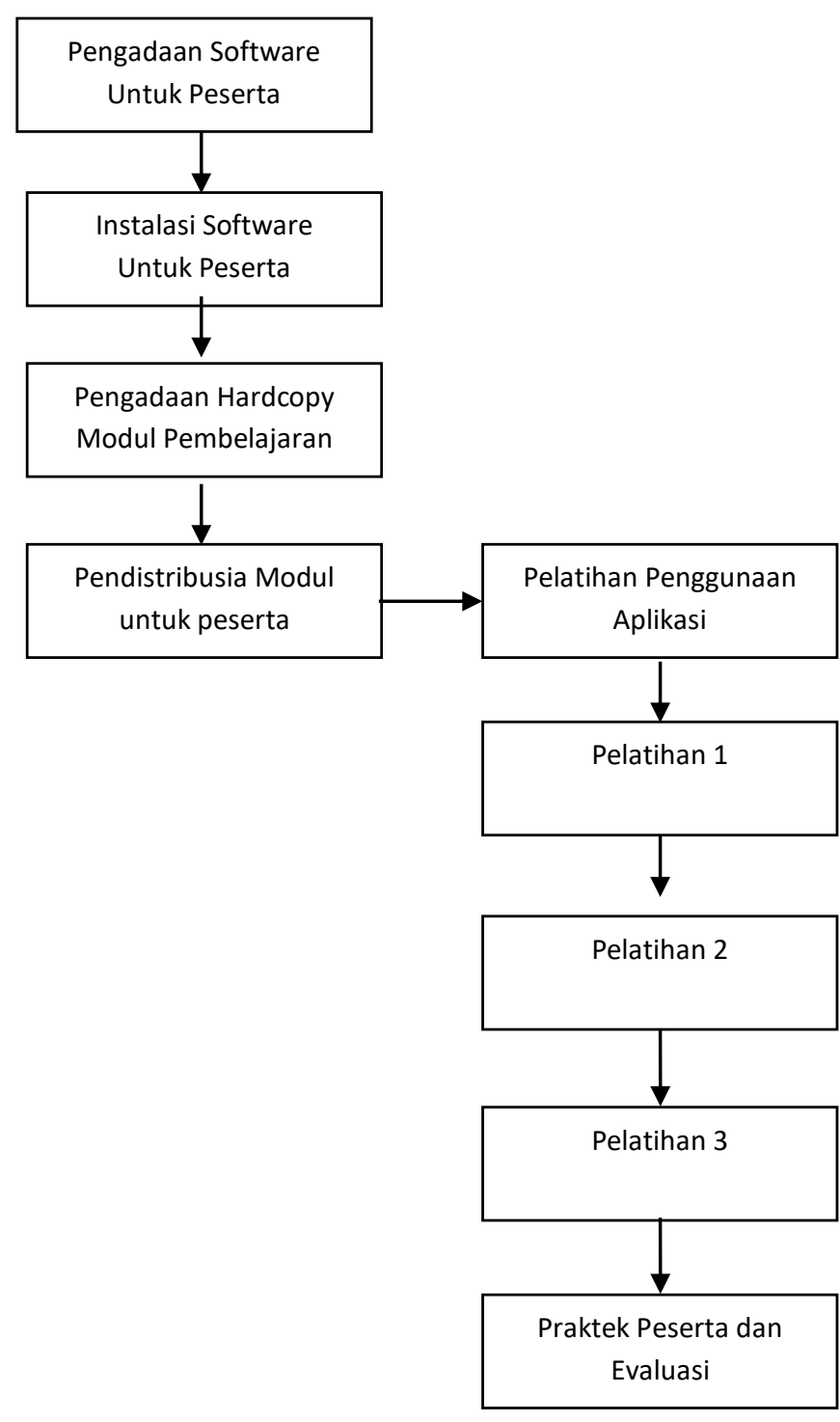

Gambar 9. Rancangan Penelitian

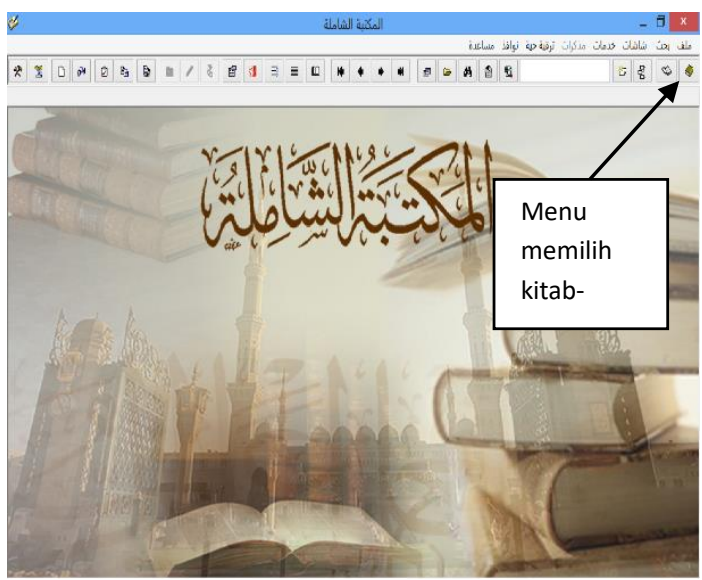

Gambar 10. Tampilan Aplikasi Shamela

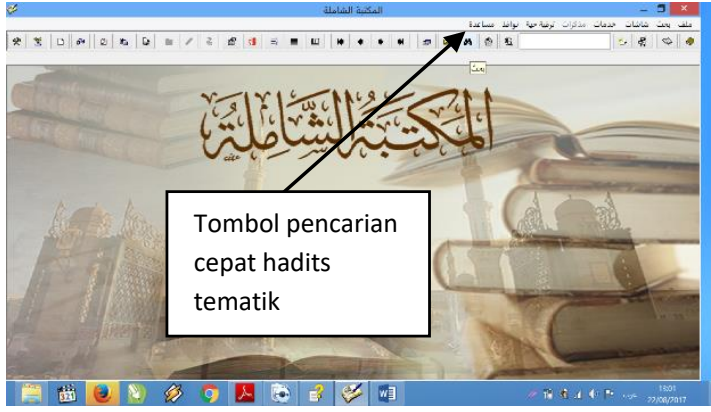

Gambar 11. Tampilan Memilih Kitab-kitab

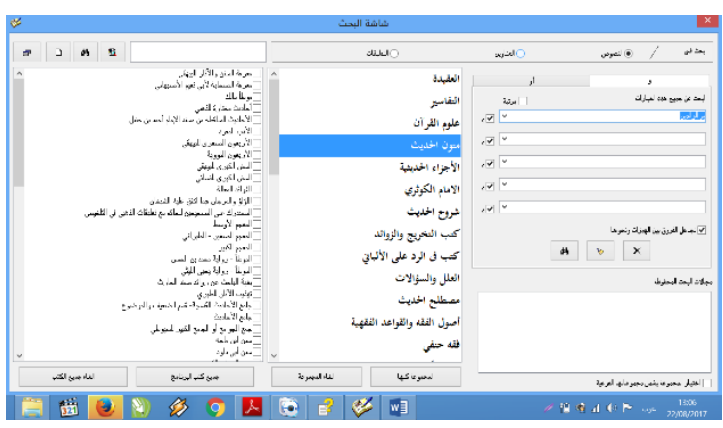

Gambar 12. Tampilan Hadits Pencarian Cepat

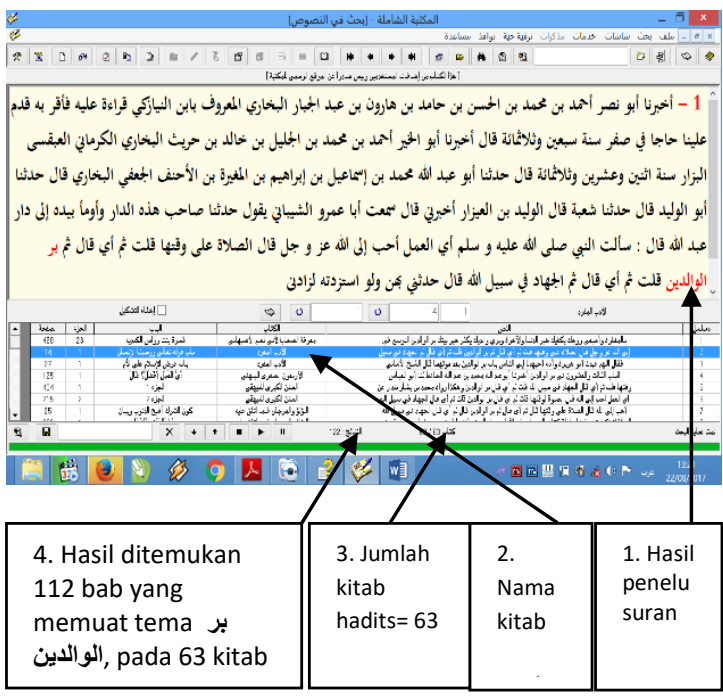

Gambar 13. Tampilan Hasil Pencarian Cepat 


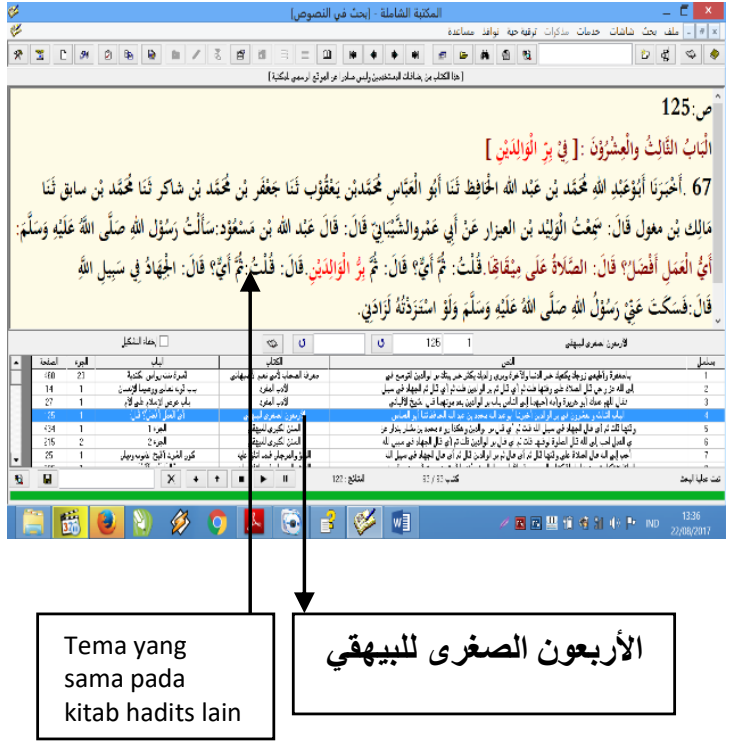

Gambar 14. Tampilan Hasil Pencarian

Pada tampilan gambar 14 di atas, mesin aplikasi shamela library dalam hitungan kurang dari 30 detik sudah bisa membaca dan menampilkan 122 hasil pencarian dari 63 judul kitab hadits. Secara kasat mata, pembelajaran hadits tematik, misalnya terkait tema berbakti kepada kedua orangtua (بر sebagaimana dalam penelitian ini dengan menggunakan media teknologi informasi seperti pemanfaat software dan aplikasi shamela library menunjukkan perbedaan yang sangat jauh antara pembelajaran manual memakai teks buku dan aplikasi.

Pembelajaran hadits atau pelajaran agama yang lain dengan menggunakan media teknologi informasi menjadi model pembelajaran baru di dunia pesantren atau madrasah. Dan model demikian ini akan meningkatkan mutu capaian pembelajaran dalam waktu yang sangat singkat dan hasil yang maksimal sebagaimana contoh pencarian hadits di atas. (Romlah, 2010). Model pembelajaran berbasis IT ini bisa dibuktikan dengan sangat mudah.

\section{KESIMPULAN DAN SARAN}

\subsection{Kesimpulan}

Bila dibandingkan membuka 1 kitab atau buku dalam hitungan 5-10 menit bisa hanya mendapatkan 1 hadits dalam satu bab, sedangkan dengan menggunakan teknologi informasi kurang dari 30 detik bisa membuka 63 kitab hadits, dengan hasil penelurusan 122 lokasi halaman kitab. Secara umum pembelajaran agama Islam, khususnya hadits tematik dengan menggunakan software dan aplikasi shamela library memberi kesimpulan sebagai berikut:

1. Teknologi informasi sangat memudahkan dan efektif untuk pengayaan ilmu pengetahuan studi Islam, khususnya di bidang hadits tematik

2. Software dan aplikasi shamela library Al-
Maktabah As-Syamilah sangat mudah untuk diimplementasikan sebagai media belajar, mendalami, meneliti, dan mengembangkan studi Islam.

3. Studi Islam akan lebih mudah, lebih efektif, dan efesien dengan memanfaatkan teknologi informasi.

4. Memudahkan para siswa dan siswi untuk memperkaya bacaan, wacana, dan wawasan keislaman

5. Memudahkan guru agama dalam pembalajaran materi hadits, dan materi agama Islam secara umum

6. Menghemat biaya pengadaan buku-buku, karena software dan aplikasi ini bisa didownload secara gratis

7. Memudahkan para siswa dan siswi lembaga Islam seperti pesantren untuk menjelajahi kitab-kitab tanpa harus mengunjungi perpustakaan, karena ia sudah menjadi e-book islami yang lebih lengkap dari perpustakaan madrasah.

\subsection{Saran}

Oleh karena software dan aplikasi adalah alat yang digunakan untuk mencapai tujuan, dalam hal ini tujuan pengayaan materi pembelajaran, maka ada beberapa saran penting untuk pengelola, pelaku, dan masyarakat pendidikan untuk berperan aktif dalam hal-hal berikut:

1. Menjadikan teknologi sebagai alat yang tepat guna dan sasaran

2. Membuka wawasan teknologi informasi sebagai alat pendidikan

3. Mengembangkan media pembelajaran yang berbasi teknologi informasi, mengingat $50 \%$ proses pembelajaran adalah transfer of knoledge

4. Penulis menyarankan kepada pihak lembaga untuk menjadi aplikasi ini sebagai perpustakaan yang disosialisasikan untuk seluruh guru materi agama Islam

5. Untuk semua guru materi agama Islam dan seluruh siswa siswi agar selalu meng-upgrade versi Al-Maktabah As-Syamilah dengan menambahkan kitab-kitab penting yang dintegrasikan dengan kurikulum yang ada

6. Untuk Pihak Institut Teknologi Nasional Malang Jurusan Informatika bisa menjadi mitra madrasah atau sekolah yang berbasis pesantren untuk pengembangan software dan aplikasi ini.

\section{UCAPAN TERIMA KASIH}

Dengan terbitnya tulisan ini peneliti mengucapkan terima kasih yang tidak terhingga kepada pihak-pihak yang telah memberi kontribusi baik langsung atau tidak langsung sebagai berikut:

1. Kajur Teknik Informatika ITN Malang 
2. Kepala Madrasah Aliyah An-Nur Al-Huda Ngawonggo Tajinan Malang

3. Siswa, santri, dan para asatidz Madrasah Aliyah An-Nur Al-Huda Ngawonggo Tajinan Malang yang membantu terselesaikannya penelitian ini.

4. Redaktur pelaksana dan editor Jurnal MNEMONIC Teknik Informatika Institut Teknologi Nasional Malang.

\section{DAFTAR PUSTAKA}

[1]. Romlah, 2010. "Pengembangan Model Pembelajaran Pendidikan Agama Islam (PAI) Berbasis Contextual Teaching and Learning
(CTL), Sebagai Upaya Meningkatkan Kualitas Pembelajaran Guru di SMP Kota Malang.” Jurnal Pemikiran dan Pendidikan Islam, Progresiva, Vol. 4, Nomor 1/Agustus 2010. ISSN: 1907-378X.

[2]. Danim, Sudarwan. 2008. Media Komunikasi Pendidikan. Jakarta: PT. Bumi Aksara

[3]. Indriana, Dina. 2011. Ragam Alat Bantu Media Pengajaran. Jogjakarta: DIVA Press

[4]. Nasution, S. 2010. Teknologi Pendidikan. Jakarta: PT Bumi Aksara

[5]. http://shamela.ws/index.php/categories

[6]. shamela.ws/index.php/search/find

[7]. (https://id.wikipedia.org/wiki/Maktabah_Syam ilah) 